\title{
Solidification and stabilization of expired chemicals
}

\author{
Sharon Ranjitha Paul ${ }^{1 *}$ and C R Ramakrishnaiah ${ }^{2}$ \\ Post Graduate Student, Environmental Engineering, Department of Civil Engineering, BMSCE, Bengaluru, \\ Karnataka, India ${ }^{1}$ \\ Professor, Department of Civil Engineering, BMSCE, Bengaluru, Karnataka, India ${ }^{2}$
}

\section{(C)2018 ACCENTS}

\begin{abstract}
Expired chemicals are treated to be hazardous waste. Not only are expired chemicals useless for an experiment, but they can also be volatile and dangerous when they exceed their date of expiry and become complicated and difficult to dispose. Once these chemicals get disposed into landfill and if there is any leaching, it leads to pollution of the environment and also affecting human health in the near vicinity. Treatment of hazardous waste is done through solidification and stabilization process designed to encapsulate inorganic hazardous wastes (heavy metals) within cement, thereby creating a non-hazardous product. In this project the expired chemicals are solidified and stabilised before their disposal. One of the main objective of the project is to optimize the mix of binders and to ensure safe disposal of chemicals into landfill in an eco-friendly and an economically viable manner and to study the leaching process of heavy metals, to optimize the process of stabilization of hazardous waste using the conventional materials like fly ash, cement \& lime which are used as binders to evaluate the quantity of heavy metals that could possibly release and harm the environment and human beings. Efficiency of the mobilization depends on parameters such as curing time, dosage of stabilizer and combination of stabilizer to reach the criteria of hazardous waste and safe disposal of this waste into the landfill.
\end{abstract}

\section{Keywords}

Solidification, Stabilization, Hazardous waste, Expired chemicals.

\section{Introduction}

Certain chemicals are unstable and within few years or even few months, tend to turn into dangerous substances. Expired chemicals are treated as to be hazardous wastes [1, 2]. Not only are expired chemicals useless for an experiment, but they can also be volatile and dangerous when they exceed their date of expiry and become complicated and difficult to dispose. Expired chemicals are a real problem in laboratory work. They pose health and safety risks as well as risks to the work being done. There are totally four characteristics in chemical wastes that will make a waste to be hazardous in nature.

Ultimate disposal of the expired chemicals would be into a landfill. Various reasons would lead to the dissolution of harmful chemicals (or materials) from landfills formed from dumping of wastes. The migration of these toxic dissolved chemicals from landfills into the natural resources like river, groundwater, etc. would lead to major environmental problems.

*Author for correspondence
The impact of the toxic agents due to the exposure poses serious health issues in human beings when their concentration increases beyond the acceptable limits. In order to prevent the leaching of chemicals, solidification and stabilization can be done in which materials are added to the waste to produce a solid which is more stable chemically as there would be a chemical bond between these wastes and the additives [3, 4]. By this process, there will be a transformation of toxic component to a new nontoxic substance, which would reduce the risk of affecting the environment adversely [5].

The present study gives an insight about optimization of the stabilizer mixes for the solidification of the expired chemicals and to know which substitute would be better between lime and fly ash to partially replace the conventional binder (cement), for the solidification-stabilization process. This project focuses on treatment/stabilization of hazardous wastes prior to the disposal into a landfill, with addition of cement, fly ash and lime also to know their concentrations discharged into the environment. 
The objectives of this study are:

- Solidification \& stabilization of the expired chemicals using lime fly ash \& cement.

- Optimization of stabilizer mix for solidification of the chemical waste.

- To arrive at a new unconventional partial substitute, for the conventional binder i.e. cement using waste substances, for the solidificationstabilization process.

- To arrive at the condition, where the heavy metal concentration in the leachate meets the required criteria for disposal when the stabilised waste is disposed into the landfill.

- To study the leaching behaviour of chemicals and also to know their concentrations discharged in the environment.

\section{Materials and methodology}

This projects aims in the safe disposal of expired chemicals into the landfill that it would not cause any leaching into the soil lying under the landfill. Solidification and stabilization technique is adopted which involves the addition of cement [6] and additives which thereby limits the solubility or mobility of the waste constituents [7, 8]. The expired chemicals were collected from the laboratories of BMS College of Engineering, Bangalore. The stabilizing agents chosen for this work are lime and fly ash (Figure 1).

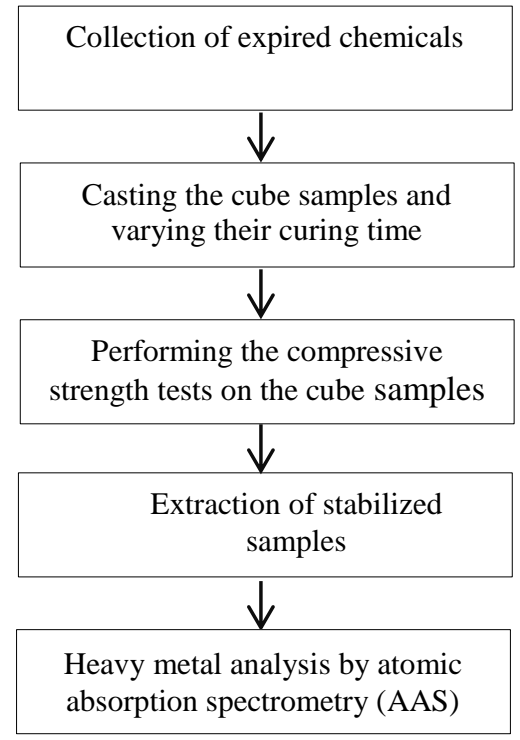

Figure 1 Methodology followed

Collection and sampling of expired was done and later arrived at mix proportions by deciding the amount of stabilisers to be added for each of the mix (Table 1). Test specimens were casted in the form of 202 cube of dimension $70.6 \mathrm{~mm} \times 70.6 \mathrm{~mm} \times 70.6 \mathrm{~mm}$. Later the specimens were tested for compression strength after 7 and 28 days of curing in the water bath. Digestion of the stabilised samples was done in order to analyse the heavy metals by atomic absorption spectrophotometer.

Table 1 Collected expired chemicals and their quantities

\begin{tabular}{lll}
\hline SI No & Chemicals & Quantity in grams \\
\hline 1 & Lead Nitrate & 4200 \\
2 & Lead II Nitrate & 1500 \\
3 & Lead Nitrate LR & 500 \\
4 & Zinc Sulphate & 500 \\
5 & Copper Nitrate & 250 \\
6 & Cadmium Sulphate & 600 \\
7 & Copper II Sulphate & 1500 \\
8 & Cupric Sulphate & 1000 \\
\hline Total quantity of expired chemicals & 10,050 \\
\hline
\end{tabular}

All the expired chemicals collected were salts of heavy metals like copper, chromium, zinc and cadmium. The total quantity of expired chemicals collected added to 10 kilograms. Initially $\mathrm{pH}$ of the chemicals was checked using $\mathrm{pH}$ meter. It was observed that the chemicals were having $\mathrm{pH}$ of less than 7 which indicated that it was acidic in nature. The mixture of expired chemicals gave out a very pungent smell. It was observed that this mixture used to easily catch the moisture if it was kept in open air for even few minutes, hence it was preserved in air tight container and thus it was maintained dry all through the course of the experimental work and also until it was casted as a cube using cement, lime and fly ash.

In order to stabilize them, the number of mixes was decided based on the quantity of the collected chemicals and also the stabilizing agents to be used in the process of stabilization was decided to be lime and fly ash [9] as another important objective of this project was to reduce the use of conventional binder which is cement and replace it with an nonconventional material that would serve the purpose as per the required criteria [10]. Proportioning of the stabilizing agents was done for the $15 \mathrm{mix}$ designs in which the cement was kept as least for the first mix which was 20:80 (cement: additives) and the maximum cement quantity was in the ratio 60:40(cement : additives) and the quantity of expired chemicals was fixed to be constant for every mix i.e. 150 grams. Cement content was kept increasing in each mix .The following Table 2 shows the quantities of cement, lime, fly ash and the expired chemicals for all the 15 mixes. 
Table 2 Proportioning the stabilizing agents

\begin{tabular}{|c|c|c|c|c|c|}
\hline \multirow[t]{3}{*}{ Mix } & \multirow[t]{3}{*}{ Cement: additives } & \multirow{3}{*}{$\begin{array}{l}\text { Expired } \\
\text { chemicals } \\
\text { (G) }\end{array}$} & \multirow{2}{*}{\multicolumn{3}{|c|}{$\begin{array}{c}\text { Quantity (G) } \\
\text { Additives +Cement }\end{array}$}} \\
\hline & & & & Additive & \\
\hline & & & Lime & Fly Ash & Cement \\
\hline \multirow[t]{2}{*}{1} & $20: 80$ & 150 & $1 / 2$ & $1 / 2$ & - \\
\hline & $160 \mathrm{~g}: 490 \mathrm{~g}$ & - & 245 & 245 & 160 \\
\hline \multirow[t]{2}{*}{2} & $20: 80$ & 150 & 1 & 0 & - \\
\hline & $160 \mathrm{~g}: 490 \mathrm{~g}$ & - & 490 & 0 & 160 \\
\hline \multirow[t]{2}{*}{3} & $20: 80$ & 150 & 0 & 1 & - \\
\hline & $160 \mathrm{~g}: 490 \mathrm{~g}$ & - & 0 & 490 & 160 \\
\hline \multirow[t]{2}{*}{4} & $30: 70$ & 150 & $1 / 2$ & $1 / 2$ & - \\
\hline & $240 \mathrm{~g}: 410 \mathrm{~g}$ & - & 205 & 205 & 240 \\
\hline \multirow[t]{2}{*}{5} & $30: 70$ & 150 & 1 & 0 & - \\
\hline & $240 \mathrm{~g}: 410 \mathrm{~g}$ & - & 410 & 0 & 240 \\
\hline \multirow[t]{2}{*}{6} & $30: 70$ & 150 & 0 & 1 & - \\
\hline & $240 \mathrm{~g}: 410 \mathrm{~g}$ & - & 0 & 410 & 240 \\
\hline \multirow[t]{2}{*}{7} & $40: 60$ & 150 & $1 / 2$ & $1 / 2$ & - \\
\hline & $320 \mathrm{~g}: 330 \mathrm{~g}$ & - & 165 & 165 & 320 \\
\hline \multirow[t]{2}{*}{8} & $40: 60$ & 150 & 1 & 0 & - \\
\hline & $320 \mathrm{~g}: 330 \mathrm{~g}$ & - & 330 & 0 & 320 \\
\hline \multirow[t]{2}{*}{9} & $40: 60$ & 150 & 0 & 1 & - \\
\hline & $320 \mathrm{~g}: 330 \mathrm{~g}$ & - & 0 & 330 & 320 \\
\hline \multirow[t]{2}{*}{10} & $50: 50$ & 150 & $1 / 2$ & $1 / 2$ & - \\
\hline & $.400 \mathrm{~g}: 250 \mathrm{~g}$ & - & 125 & 125 & 400 \\
\hline \multirow[t]{2}{*}{11} & $50: 50$ & 150 & 1 & 0 & - \\
\hline & $400 \mathrm{~g}: 250 \mathrm{~g}$ & & 250 & 0 & 400 \\
\hline \multirow[t]{2}{*}{12} & $50: 50$ & 150 & 0 & 1 & - \\
\hline & $400 \mathrm{~g}: 250 \mathrm{~g}$ & - & 0 & 250 & 400 \\
\hline \multirow[t]{2}{*}{13} & $60: 40$ & 150 & $1 / 2$ & $1 / 2$ & - \\
\hline & $480 \mathrm{~g}: 170 \mathrm{~g}$ & - & 85 & 85 & 480 \\
\hline \multirow[t]{2}{*}{14} & $60: 40$ & 150 & 1 & 0 & - \\
\hline & $480 \mathrm{~g}: 170 \mathrm{~g}$ & - & 170 & 0 & 480 \\
\hline \multirow[t]{2}{*}{15} & $60: 40$ & 150 & 0 & 1 & - \\
\hline & $480 \mathrm{~g}: 170 \mathrm{~g}$ & - & 0 & 170 & 480 \\
\hline
\end{tabular}

\section{Results and discussions}

The experiments were conducted by varying the dosage of the binders at different combinations and also the duration of the curing time. The solidification and stabilization studies were performed at laboratory scale, where the expired chemicals was mixed with various proportions of stabilizing agents like cement, fly ash, and lime in different combinations and duration of curing, so as to solidify it for secure landfill disposal with the reduction in heavy metal concentration [11-13]. To identify which mix would reduce the concentration of heavy metal in the leachate before it has been disposed of into a secured landfill. The collected expired chemicals were checked for the heavy metal content in AAS before the process of stabilization was started. It was revealed that the sample had a very high content of copper (i.e. $853.87 \mathrm{ppm}$ ) as shown in Table 3.

Out of the 15 mix proportions casted into cubes, 5 of the mixes after casting into cubes got brittle soon as they were placed into the curing bath and their strength was not reached. The 5 mixes that failed to reach the strength are shown in Table 4. After 7 and 28 of the casting of cube samples, the cubes were tested for compressive strength (Table 5) in universal testing machine. Expect the cubes of batch 5, rest all gave the compressive strength of greater than 0.35 $\mathrm{N} / \mathrm{mm}^{2}$, which is the criterion of compressive strength required for the disposal into the landfill. The following Figures 2 and 3 shows the 7 days and 
28 days compressive strength for all the mixes. It was observed that the water prior to the placement of cubes for curing was tested for heavy metals and it showed no presence of $\mathrm{Cu}, \mathrm{Ni}$ or $\mathrm{Cr}$. Later when the same water was testes for the heavy metal after the cubes were taken out after 28 days then there was presence of $\mathrm{Cu}, \mathrm{Ni}$ and $\mathrm{Cr}$.
The Table 8 will give the values of the heavy metals in the water observed before and after the cubes were placed in the water for curing. Table 6 shows the heavy metal content of the stabilised samples after 7 days curing period. Table 7 shows the heavy metal content of the stabilised samples after 28 days curing period.

Table 3 Heavy metal concentration in the sample

\begin{tabular}{ll}
\hline Heavy metal concentration in expired chemicals & Acid leaching before stabilization (PPM) \\
\hline $\mathrm{Cu}$ & 853.87 \\
$\mathrm{Cr}$ & 0.85 \\
$\mathrm{Ni}$ & 0.63 \\
$\mathrm{Cd}$ & 0.078 \\
$\mathrm{Fe}$ & 0.090 \\
$\mathrm{As}$ & 0.040 \\
$\mathrm{Zn}$ & 0.038 \\
\hline
\end{tabular}

Table 4 Failed set of mixes when kept for curing

\begin{tabular}{rccccc}
\hline S. No & Cement: additives & Cement(G) & Lime(G) & Fly ash(G) & Chemicals(G) \\
\hline 1 & $20: 80$ & 160 & 490 & 0 & 150 \\
2 & $20: 80$ & 160 & 0 & 490 & 150 \\
3 & $30: 70$ & 240 & 410 & 0 & 150 \\
4 & $30: 70$ & 240 & 0 & 410 & 150 \\
5 & $50: 50$ & 400 & 0 & 250 & 150 \\
\hline
\end{tabular}

Table 5 Unconfined compressive strength (UCS) of solidified samples

\begin{tabular}{|c|c|c|c|}
\hline Batch No. & MIX & $\begin{array}{l}7 \text { Days compressive } \\
\text { strength }\left(\mathrm{N} / \mathbf{M M}^{2}\right)\end{array}$ & $\begin{array}{l}\text { 28Days compressive } \\
\text { strength }\left(\mathrm{N} / \mathrm{MM}^{2}\right)\end{array}$ \\
\hline 1 & 20:80 ( Cement: Lime, Fly Ash, Chemicals) & 0.461 & 1.906 \\
\hline 2 & 30:70 ( Cement: Lime, Fly Ash, Chemicals) & 0.682 & 3.404 \\
\hline 3 & 40:60 ( Cement :Lime, Fly Ash, Chemicals) & 2.046 & 8.828 \\
\hline 4 & 40:60 ( Cement: Lime, Chemicals) & 1.023 & 2.430 \\
\hline 5 & 40:60 ( Cement: Fly Ash, Chemicals) & 0.327 & 0.952 \\
\hline 6 & 50:50 (Cement: Lime, Fly Ash, Chemicals) & 3.389 & 12.372 \\
\hline 7 & 50:50 (Cement: Lime, Chemicals) & 0.451 & 1.976 \\
\hline 8 & 60:40 (Cement: Lime, Fly Ash, Chemicals) & 1.775 & 5.196 \\
\hline 9 & 60:40 ( Cement: Fly Ash, Chemicals) & 0.962 & 1.226 \\
\hline 10 & 60:40 ( Cement: Lime, Chemicals) & 3.213 & 20.665 \\
\hline
\end{tabular}

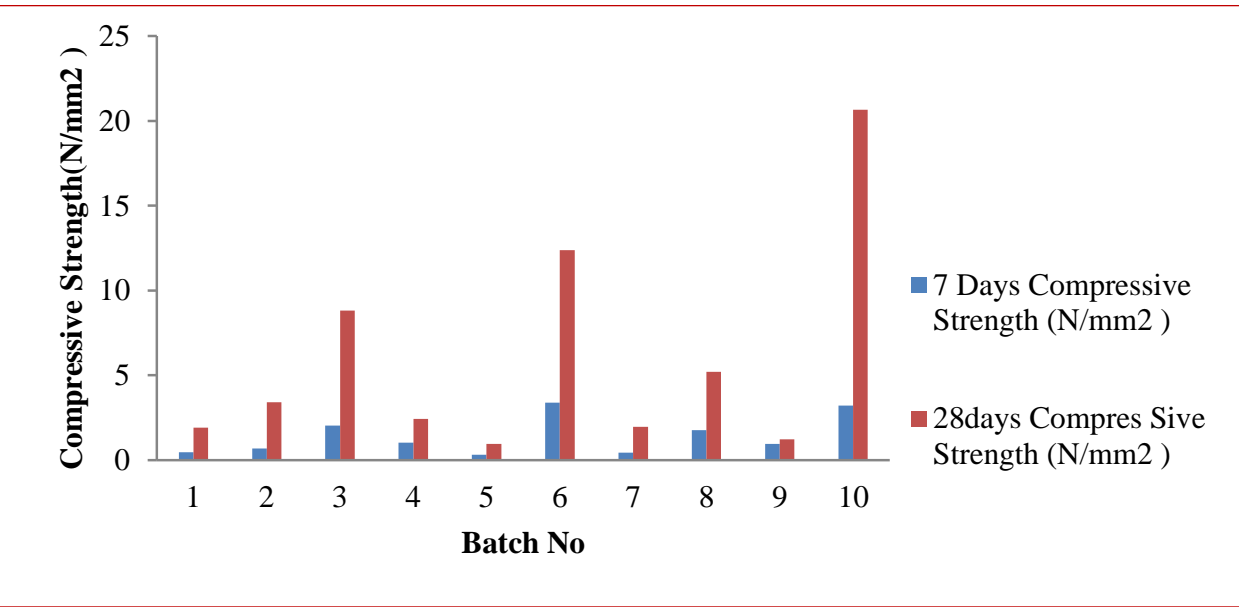

Figure 2 UCS of stabilized samples after $7 \& 28$ days of curing 
Table 6 Heavy metal content of the stabilised samples after 7 days curing period

\begin{tabular}{llll}
\hline Batch No & Cr $(\mathbf{p p m})$ & $\mathbf{C u}(\mathbf{p p m})$ & $\mathbf{N i}(\mathbf{p p m})$ \\
\hline 1 & 0.32 & 64.56 & 0.54 \\
2 & 0.33 & 84.65 & 0.47 \\
3 & 0.56 & 71.45 & 0.31 \\
4 & 0.46 & 157.94 & 0.35 \\
5 & 0.52 & 180.56 & 0.58 \\
6 & 0.05 & 71.56 & 0.39 \\
7 & 0.12 & 77.96 & 0.25 \\
8 & 0.44 & 93.42 & 0.22 \\
9 & 0.56 & 164.34 & 0.40 \\
\hline
\end{tabular}

Table 7 Heavy metal content of the stabilised samples after 28 days curing period

\begin{tabular}{llll}
\hline Batch No & Cr $(\mathbf{p p m})$ & $\mathbf{C u}(\mathbf{p p m})$ & $\mathbf{N i}(\mathbf{p p m})$ \\
\hline 1 & 0.29 & 41.56 & 0.41 \\
2 & 0.31 & 32.05 & 0.39 \\
3 & 0.18 & 29.34 & 0.25 \\
4 & 0.42 & 28.42 & 0.32 \\
5 & 0.38 & 42.56 & 0.48 \\
6 & 0.02 & 30.2 & 0.33 \\
7 & 0.1 & 31.55 & 0.18 \\
8 & 0.32 & 28.47 & 0.12 \\
9 & 0.28 & 23.09 & 0.2 \\
10 & 0.22 & 25.81 & 0.11 \\
\hline
\end{tabular}

Table 8 Heavy metal content in the water before and after the curing of the samples

\begin{tabular}{|c|c|c|c|c|c|c|}
\hline \multirow[t]{2}{*}{$\begin{array}{c}\text { Batch } \\
\text { No }\end{array}$} & \multicolumn{3}{|c|}{$\begin{array}{c}\text { Curing water tested for heavy metal content } \\
\text { before cubes were placed }\end{array}$} & \multicolumn{3}{|c|}{$\begin{array}{c}\text { Curing water tested for heavy metal content after } \\
\text { cubes were placed }\end{array}$} \\
\hline & $\mathrm{Cr}(\mathbf{p p m})$ & $\mathrm{Cu}(\mathrm{ppm})$ & Ni(ppm) & $\mathrm{Cr}$ (ppm) & $\mathrm{Cu}$ (ppm) & $\mathrm{Ni}(\mathbf{p p m})$ \\
\hline 1 & 0.0 & 0.0 & 0.0 & 0.02 & 0.85 & 0.02 \\
\hline 2 & 0.0 & 0.0 & 0.0 & 0.02 & 0.64 & 0.01 \\
\hline 3 & 0.0 & 0.0 & 0.0 & 0.01 & 0.68 & 0.03 \\
\hline 4 & 0.0 & 0.0 & 0.0 & 0.03 & 0.51 & 0.02 \\
\hline 5 & 0.0 & 0.0 & 0.0 & 0.08 & 0.71 & 0.05 \\
\hline 6 & 0.0 & 0.0 & 0.0 & 0.03 & 0.51 & 0.01 \\
\hline 7 & 0.0 & 0.0 & 0.0 & 0.00 & 0.53 & 0.04 \\
\hline 8 & 0.0 & 0.0 & 0.0 & 0.01 & 0.24 & 0.01 \\
\hline 9 & 0.0 & 0.0 & 0.0 & 0.01 & 0.05 & 0.01 \\
\hline 10 & 0.0 & 0.0 & 0.0 & 0.02 & 0.09 & 0.03 \\
\hline
\end{tabular}

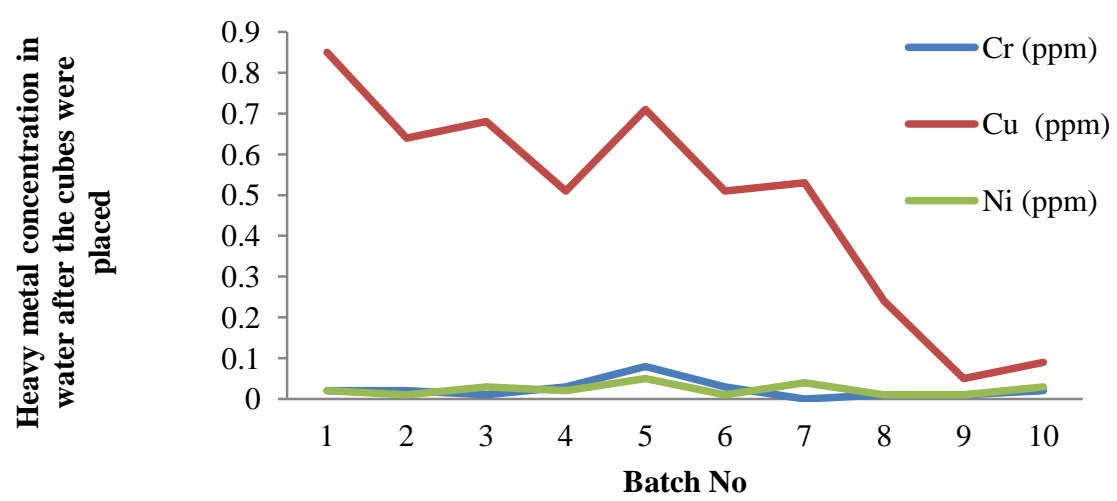

Figure 3 Heavy metal content in the water before and after the curing of the samples 


\section{Conclusion and future work}

Except batch 5 mix, rest of the stabilized mix design samples of expired chemicals proved to be very effective for solidification as their UCS values were much greater than minimum criteria value prescribed for disposal in to secure landfill i.e. $0.35 \mathrm{~N} / \mathrm{mm} 2$.

The best mixes (in terms of UCS), have showed exceptionally high values of compressive strengths (nearly 34 to 57 times the minimum criteria value), indicating the enormous success of the use of the binding material lime, cement, fly ash for solidification. The mixes which had lesser proportion of cement with greater proportion of fly ash with a constant proportion of expired chemicals proved to be very brittle and also showed least compressive strength when tested in UTM. The mixes with a greater proportion of cement, and lesser proportion of binding agents, showed greater stabilization effectiveness, validating the use of the two stabilizing agents as successful stabilizers. It is also noticed that expired chemicals, when used along with cement, fly ash and lime shows a higher rate of reduction in concentration of metals, in the leachate than when applied with only cement and lime or cement and fly ash. For a particular cement: additive ratio, and the same proportion of expired chemicals, the mixes with a greater proportion of cement and equal proportion of lime and fly ash proved to be more effective. It was also observed that the mix with least cement content in it i.e. 20:80 of cement : additives mix showed compressive strength of $0.416 \mathrm{~N} / \mathrm{mm}^{2}$ for 7 days and $1.906 \mathrm{~N} / \mathrm{mm}^{2}$ for 28 days, where both the compressive strength of 7 and 28 days were greater than the landfill disposal criteria which is $0.35 \mathrm{~N} / \mathrm{mm}^{2}$.

In the extraction tests and the determination of heavy metal concentration in AAS has shown that all the three heavy metals present in the expired chemicals which are copper, chromium and nickel are within their permissible levels of disposal into landfill.The heavy metal concentration of $\mathrm{Cr}=0.02 \mathrm{ppm}, \mathrm{Cu}=$ $30.2 \mathrm{ppm}$ and $\mathrm{Ni}=0.33 \mathrm{ppm}$ was seen for the best mix with respect to the compressive strength for 28 days to be $20.665 \mathrm{~N} / \mathrm{mm}^{2}$.

Further this study can be extended for various other set of expired chemical stabilization also can be used to know the chemical reactions that take place during the process of stabilization and how they would impact the strength of the cube. Heavy metal removal can be investigated by using various other stabilizing agents.
Acknowledgment

None.

\section{Conflicts of interest}

The authors have no conflicts of interest to declare.

\section{References}

[1] Nascimento ED, Tenuta Filho A. Chemical waste risk reduction and environmental impact generated by laboratory activities in research and teaching institutions. Brazilian Journal of Pharmaceutical Sciences. 2010; 46(2):187-98.

[2] Manual WM. United states environmental protection agency. Government Institutes Inc. 1988:1-5.

[3] Conner JR. Chemical fixation and solidificationof hazardous wastes. Van Nostrand Reinhold, New York. 1990; 692(1990):335.

[4] BISHOP PL. Leaching of inorganic hazardous constituents from stabilized/solidified hazardous wastes. Hazardous Waste and Hazardous Materials. 1988; 5(2):129-43.

[5] Leong ST, Laortanakul P. An environmentally optimized solidification/stabilization for disposal of heavy metal sludge wastes. Science \& Technology Asia, 2002; 7(3):22-39.

[6] Sobiecka E. Investigating the chemical stabilization of hazardous waste material (fly ash) encapsulated in Portland cement. International Journal of Environmental Science and Technology. 2013; 10(6):1219-24.

[7] Yilmaz O, Ünlü K, Cokca E. Solidification/stabilization of hazardous wastes containing metals and organic contaminants. Journal of Environmental Engineering. 2003; 129(4):366-76.

[8] Lambert M, Leven BA, Green RM. New methods of cleaning up heavy metal in soils and water. Environmental science and technology briefs for citizens. Kansas State University, Manhattan, KS. 2000.

[9] Teggihalli TM, Ramakrishnaiah CR. Solidification/Stabilization of Zinc phosphating and AETP sludge using a novel combination of cement with a sintered waste additive. International Research Journal of Engineering and Technology, 2017: 23950056.

[10] Ramakrishnaiah CR, Duvvuri S. Stabilization of metal-laden soils using different additives-a review of technologies. International Research Journal of Pure and Applied Chemistry. 2015; 7(3):122-31.

[11] Goyal MK, Chauhan A. Environmental pollution remediation through solidification/fixation of heavy metal ions in Portland cement. Journal of Environmental \& Analytical Toxicology. 2015; 5(6):1.

[12] Chen L, Liu SY, Du YJ, Jin F. Strength comparison of cement solidified/stabilized soils contaminated by lead and copper. In geoenvironmental engineering and geotechnics: progress in modeling and applications 2010 (pp. 103-10). 
[13] Lasheen MR, Ashmawy AM, Ibrahim HS, Moniem SM. Pozzolanic-based materials for stabilization/solidification of contaminated sludge with hazardous heavy metal: case study. Desalination and Water Treatment. 2013; 51(13-15):2644-55.

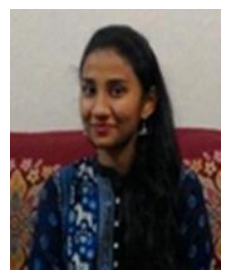

Sharon Ranjitha Paul pursuing M.Tech in Environmental Engineering at BMS College of Engineering, Basavangudi, Bengaluru, Karnataka, India. Her research interset are Solidification and Stabilization of Expired Chemicals and Environmental Engineering.

Email: sharon.rymec@gmail.com

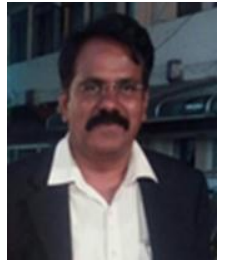

Ramakrishnaiah. C.R. completed his $\mathrm{PhD}$ in the year 2010, in the area of Environmental Engineering from Visvesvaraya Technological University, Belgaum, Karnataka, India. $\mathrm{He}$ is currently working as Associate Professor in the department of Civil Engineering, BMS College of Engineering. He has published 22 international journals and 1 National journal. He has a teaching experience of 24 years. 